\title{
NS-398 induces caspase-dependent, mitochondria-mediated intrinsic apoptosis of hepatoma cells
}

\author{
Il Han Song, , Suk Bae Kim, Hyun Duk Shin, Ha Yan Kang, Eun Young Kim \\ Division of Hepatology and Gastroenterology, Department of Internal Medicine, Dankook University College of Medicine, Dankook \\ University Hospital Institute of Medical Science, Cheonan, Korea \\ Email: *ihsong21@,dankook.ac.kr
}

Received 2 July 2012; revised 15 August 2012; accepted 5 September 2012

\begin{abstract}
The present study was conducted to investigate whether mitochondrial pathway of apoptosis is involved in cyclooxygenase-2 (COX-2) inhibitor-induced growth inhibition of hepatoma cells. The growth rate and pattern of NS-398 (selective COX-2 inhibitor)-treated Hep3B hepatoma cells were analyzed by microscopic examination, DNA fragmentation gel analysis and flow cytometry followed by the cleavage of downstream caspase 3 and the release of cytosolic fraction of cytochrome c assessed by Western blot analysis. NS-398 induced the growth inhibittion of hepatoma cells depending on the concentration of this $\mathrm{COX}-2$ inhibitor and time sequence. Ladder patterned-DNA fragmentation and cytometric redistribution to subG1 phase in cell cycle were revealed in NS-398-induced growth inhibition of hepatoma cells. Cytochrome c was translocated from mitochondria to cytosol in time-dependent manner following NS-398 treatment to hepatoma cells. COX-2 inhibitor induces the growth inhibition of hepatoma cells via caspasedependent, mitochondria-mediated intrinsic apoptosis pathway. These results strongly suggest the possibility of therapeutic implication of COX-2 inhibitor in HCC.
\end{abstract}

Keywords: Hepatocellular Carcinoma; Cyclooxygenase-2 (COX-2); COX-2 Inhibitor; Apoptosis; Western Blotting; Flow Cytometry; DNA

\section{INTRODUCTION}

Hepatocellular carcinoma (HCC) is a growing health problem worldwide, which is the fifth most common malignancy in incidence and the third leading cause in cancer-related mortality [1-3]. In advanced stage of HCC beyond clinical indications for curative treatment mo-

"Corresponding author. dalities such as surgical resections or percutaneous ablations, no effective systemic therapies but recently introduced molecular targeted agent are present by this time [4-6].

Cyclooxygenases (COX), the key enzymes involved in the metabolic conversion of arachidonic acid to prostaglandins, consist of at least two isoforms, constitutive form of COX-1 and inducible form of COX-2. Since the overexpression of COX-2 was known to be associated with neoangiogenic, antiapoptotic, and invasive or metastatic property in certain cell types [7-11], COX-2 has come to the surface as a therapeutic target of several malignant tumors including HCC. Several growing evidences of preclinical studies have indicated that COX-2 inhibitors exert antineoplastic effects on hepatoma cells both in vitro and in vivo [12-18]. However, the degree of impact of COX-2 inhibitor on growth control of heaptoma cells are controversial and its growth inhibitory mechanisms remain unclear thus far.

Major signaling pathways of apoptosis, extrinsic death receptor-mediated and intrinsic mitochondria-mediated, are usually carried out through the activation of downstream effector caspases in cytoplasm, resulting in the cleavage of cellular substrates relevant to the morphological and biochemical constellations of apoptotic phenotype $[19,20]$. Among these pathways, mitochondriamediated apoptosis progresses to the cascade activation of initiator caspase 9 and effector caspase 3 via cytoplasmic translocation of cytochrome $\mathrm{c}$ from mitochondria [21-23].

In the present study, we tried to evaluate whether COX-2 inhibitor induces the growth inhibition of heaptoma cells and engages a caspase-dependent, mitochondrial-mediated apoptosis signaling pathway in HCC.

\section{MATERIALS AND MEHODS}

\subsection{Cell Line and Culture}

The human HCC cell line, Hep3B, was purchased from 
Korean Cell Line Bank (Seoul, Korea). Hep3B cells were cultured in Dulbecco's Modified Eagle Medium (Gibco BRL, Hyclone laboratories, Lagan, Utah, USA), supplemented with $10 \%$ fetal bovine serum (FBS) and $1 \%$ penicillin/streptomycin in a humidified incubator supplied with $5 \% \mathrm{CO}_{2}$ at $37^{\circ} \mathrm{C}$ atmosphere.

\subsection{Treatment of Selective COX-2 Inhibitor to Hepatoma Cells}

NS-398 (N-[2-(cyclohexyloxy)-4-nitrophenyl]methanesulfonamide), dissolved in demethyl sulfoxide (DMSO), was used as a selective COX-2 inhibitor. We prepared the culture media in concentrations of $0,10,100$, and $200 \mu \mathrm{M}$ NS-398 for concentration-oriented experiments. Hepatoma cells were plated at a density of $1 \times 10^{5}$ cells/well in six-well plastic dishes with $2 \mathrm{~mL}$ of $10 \%$ FBS-supplemented medium. After $24 \mathrm{~h}$ exposure of NS-398, the media were changed with other new media containing same concentration of NS-398, and then the cells were incubated for $72 \mathrm{~h}$.

\subsection{Microscopic Examination}

After discarding the media with floating cells, we microscopically observed the cells continuously for three days for time-oriented experiments under $\times 20$ magnification and compared the growth pattern of cell proliferation between controls (DMSO-treated cells) and NS-398treated cells according to sequential time course of 24 , 48 , and $72 \mathrm{~h}$.

\subsection{DNA Fragmentation Gel Analysis}

Hepatoma cells were harvested at 24, 48, and $72 \mathrm{~h}$ after treatment of various concentrations of NS-398. The cells dissolved with lysis buffer were centrifuged at 10,000 g for $30 \mathrm{~min}$. For DNA extraction, the supernatant was digested with $50 \mathrm{ng} / \mathrm{mL}$ proteinase $\mathrm{K}$ at $37^{\circ} \mathrm{C}$ for $24 \mathrm{~h}$, and precipitated with a equal volume of absolute ethanol. For RNA elimination, the pellet was incubated with a Tris-EDTA buffer containing $10 \mu \mathrm{g} / \mathrm{mL}$ RNase A at $37^{\circ} \mathrm{C}$ for $1 \mathrm{~h}$. The amount of extracted DNA was measured by spectrophotometric analysis. Each DNA sample was electrophoresed on $1.8 \%$ agarose gel containing 0.5 $\mathrm{mg} / \mathrm{L}$ ethidium bromide, and photographed under ultraviolet (UV) light.

\subsection{Flow Cytometric Analysis}

Cell cycle distribution was determined by flow cytometric analysis. After treatment of NS-398, the cells were collected by trypsinization, washed twice with phosphate-buffered saline (PBS), and fixed overnight in $70 \%$ ethanol at $4^{\circ} \mathrm{C}$. The cells were stained with $50 \mu \mathrm{g} / \mathrm{mL}$ propidium iodide at room temperature for $30 \mathrm{~min}$ in the dark, following to be incubated with $50 \mu \mathrm{g} / \mathrm{mL}$ RNase A at $37^{\circ} \mathrm{C}$ for $1 \mathrm{~h}$. Then cell cycle components were analyzed by a flow cytometer and CellQuest software.

\subsection{Western Blot Analysis}

NS-398-treated hepatoma cells were prepared by washing in PBS and dissolving in lysis buffer $(50 \mathrm{mmol} / \mathrm{L}$ Tris $\mathrm{pH} 7.5,250 \mathrm{mmol} / \mathrm{L} \mathrm{NaCl}_{2}, 0.5 \%$ Triton X-100, 1 $\mathrm{mmol} / \mathrm{L}$ EDYA, $1 \mathrm{mmol} / \mathrm{L}$ PMSF, $1 \mathrm{mmol} / \mathrm{L} \mathrm{Na}_{3} \mathrm{VO}_{4}, 1$ $\mathrm{mmol} / \mathrm{L}$ dithiothreitol, $10 \mu \mathrm{g}$ of leupeptin/mL and $10 \mu \mathrm{g}$ of aprotinin $/ \mathrm{mL}$ ). After centrifugation of cell lysates for $10 \mathrm{~min}$ at $14,000 \mathrm{~g}$, the protein concentrations of supernatant in the homogenate were determined by bicinchoninic acid assay (Pierce Co, Rockford, IL, USA) according to the manufacturer's instructions. $40 \mu \mathrm{g}$ of protein in each extract was separated by $15 \%$ SDS-polyacrylamide gel, and electronically transferred to nitrocellulose membrane. The membrane was blocked with $5 \%$ fat free dry milk in TBS-T $(25 \mathrm{mmol} / \mathrm{L}$ Tris- $\mathrm{HCl}, \mathrm{pH}$ $7.5,100 \mathrm{mmol} / \mathrm{L} \mathrm{NaCl}, 0.5$ Tween-20), incubated with primary antibody for overnight at $4^{\circ} \mathrm{C}$, washed three times in TBS-T for $10 \mathrm{~min}$, and then incubated with horseradish peroxidase-conjugated secondary antibody for $1 \mathrm{~h}$ at room temperature. The immunoblotting signals were developed with an ECL system (Amersham Life Sciences, Buckinghamshire, UK). Anti- $\beta$-actin (1:1000, Santa Cruz Biotechnology Inc, Santa Cruz, CA, USA) was used as a protein loading control.

\subsection{Preparation of Mitochondrial and Cytosolic Extracts for Localization of Cytochrome c}

The cell pellets were obtained from NS-398-treated hepatoma cells that were washed, centrifugated, and resuspended in a buffer containing $25 \mathrm{mM}$ Tris ( $\mathrm{pH}$ 7.4), $250 \mathrm{mM}$ sucrose, $10 \mathrm{mM} \mathrm{KCl}, 1.5 \mathrm{mM} \mathrm{MgCl}, 1 \mathrm{mM}$ EDTA, $1 \mathrm{mM}$ EGTA, and $1 \mathrm{mM}$ DTT. The resuspened cells were homogenized ten times with Dounce homogenizer (Wheaton Scientific Products, Millville, New Jersey, USA) after adding protease inhibitor (10 $\mu \mathrm{g}$ of leupeptin $/ \mathrm{mL}, 10 \mu \mathrm{g}$ of aprotinin/mL, and $1 \mathrm{mM}$ PMSF) and phosphatase inhibitor $\left(10 \mu \mathrm{M} \mathrm{Na} \mathrm{VO}_{4}\right)$. Unlysed cells and nuclei were discarded by centrifugation at $750 \mathrm{~g}$ for $10 \mathrm{~min}$. The supernatant was centrifugated at $10,000 \mathrm{~g}$ for $30 \mathrm{~min}$, and the resulting pellet, which indicates the mitochondrial-enriched fraction, was washed once with the same buffer. The remnant supernatant was further centrifugated at $10,000 \mathrm{~g}$ for $1 \mathrm{~h}$, representing the cytosol fraction of final supernatant. Each $40 \mu \mathrm{g}$ of cytosolic and mitochondrial fractions were used for cytochome c immunoblotting described above.

\subsection{Statistical Analysis}

Statistical analysis was carried out using SPSS software 
system (SPSS Inc., Chicago, IL, USA). Data were expressed as the mean \pm SD of at least three-times independent experiments. Student's t-test and ANOVA analysis were applied to verify the statistical difference as $\mathrm{P}<$ 0.05 between experimental groups.

\section{RESULTS}

\subsection{COX-2 Inhibitor Induced Growth Inhibition of Hepatoma Cells}

After treatment of Hep3B cells with NS-398, cell number progressively decreased up to $72 \mathrm{~h}$, while the number of DMSO-treated cells exponentially increased within the same time period (Figure 1). This pattern of COX-2 inhibitor-induced growth inhibition was more prominent in cells treated with $200 \mu \mathrm{M}$ concentration than in cells treated with $100 \mu \mathrm{M}$ concentration of NS-398, indicating the both concentration-dependent and time-dependent inhibition of hepatoma cells.

\subsection{COX-2 Inhibitor Induced DNA Fragmentation and Cell Cycle Redistribution of Hepatoma Cells}

Regardless of concentrations of this compound applied in the present study, genomic DNA of Hep3B cells was fragmented as ladder-pattern at $48 \mathrm{~h}$ after the treatment of NS-398, which represented an apoptosis induced by this selective COX-2 inhibitor, but no definite DNA ladder was found after DMSO treatment (Figure 2). Flow cytometric shifting to sub-G1 phase, indicating an apoptotic redistribution of cell cycle, was gradually intensified from 6 to $48 \mathrm{~h}$ after the exposure of NS-398, while it was not observed in control part of DMSO treatment (Figure 3(a)). Namely, sub-G1 fraction of NS-398-exposed cells increased from $3.0 \% \pm 2.1 \%$ at $6 \mathrm{~h}$ to $7.0 \% \pm$ $3.8 \%$ at $48 \mathrm{~h}(100 \mu \mathrm{M} \mathrm{NS}-398)$ and from $3.0 \% \pm 1.9 \%$ at $6 \mathrm{~h}$ to $18.0 \% \pm 6.4 \%$ at $48 \mathrm{~h}(200 \mu \mathrm{M}$ NS-398) (Figure 3(b)). This cytometric redistribution was more conspicuous in $200 \mu \mathrm{M} \mathrm{NS}-398$-treated cells than in cells treated with $100 \mu \mathrm{M}$ concentration.

\subsection{COX-2 Inhibitor Induced Caspase-Dependent, Mitochondria-Mediated Apoptosis}

The activation of caspase 3 , a down-stream caspase of apoptosis pathway, was elicited from 24 to $72 \mathrm{~h}$ after treatment of both concentrations 100 and $200 \mu \mathrm{M}$ NS398 to Hep3B cells in time-dependent manner (Figure 4(a)). The relative expression of activated caspase 3 to $\beta$-actin significantly increased up to $72 \mathrm{~h}$ following the exposure of COX-2 inhibitor to hepatoma cells, which was $0.96 \pm 0.18,1.18 \pm 0.21$, and $1.50 \pm 0.19(\mathrm{P}<0.05)$ at 24,48 , and $72 \mathrm{~h}$ in case of $100 \mu \mathrm{M}$ NS-398, respec- tively, and $0.96 \pm 0.15,1.19 \pm 0.18$, and $1.30 \pm 0.20(\mathrm{P}<$ 0.05 ) at 24,48 , and $72 \mathrm{~h}$ in case of $200 \mu \mathrm{M}$ NS-398, respectively (Figure 4(b)). In company with this observation, a cytosolic accumulation of cytochrome $\mathrm{c}$, which means the release of cytochrome $\mathrm{c}$ from mitochondria, gradually increased in sequences of the same time (Figure 5(a)). The relative expression of cytosolic fraction of cytochrome c to $\beta$-actin significantly increased up to $72 \mathrm{~h}$ following the exposure of COX-2 inhibitor to hepatoma cells, which was $0.17 \pm 0.14,0.28 \pm 0.19$, and $0.31 \pm$ $0.21(\mathrm{P}<0.05)$ at 24,48 , and $72 \mathrm{~h}$ in case of $100 \mu \mathrm{M}$ NS398 , respectively, and $0.12 \pm 0.11,0.18 \pm 0.15$, and 0.31 $\pm 0.16(\mathrm{P}<0.05)$ at 24,48 , and $72 \mathrm{~h}$ in case of $200 \mu \mathrm{M}$ NS-398, respectively (Figure 5(b)). It may be suggested that NS-398, selective COX-2 inhibitor, engages a caspase-dependent, mitochondria-mediated intrinsic apoptosis

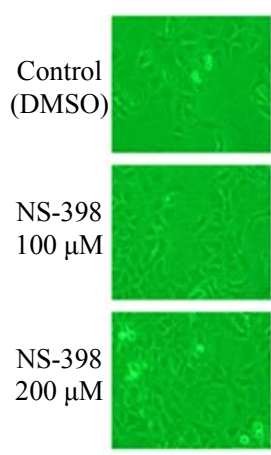

$0 \mathrm{~h}$
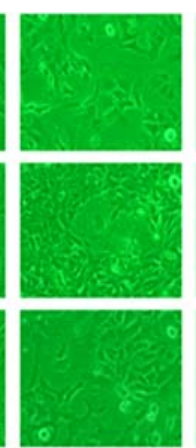

$24 \mathrm{~h}$
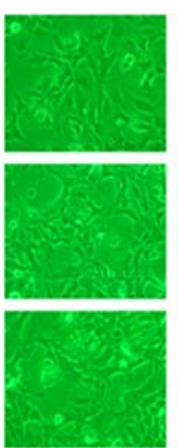

$48 \mathrm{~h}$
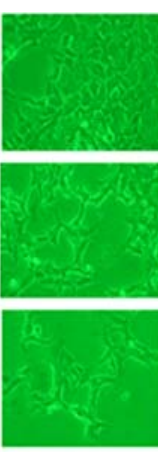

$72 \mathrm{~h}$
Figure 1. Microscopic morphology of NS-398-treated cells. NS-398 induced a progressive decrease in cell number from 24 $\mathrm{h}$ to 48 and $72 \mathrm{~h}$ after treatment of NS-398, indicating a growth inhibition of hepatoma cells with the both concentration-dependent and time-dependent manners.

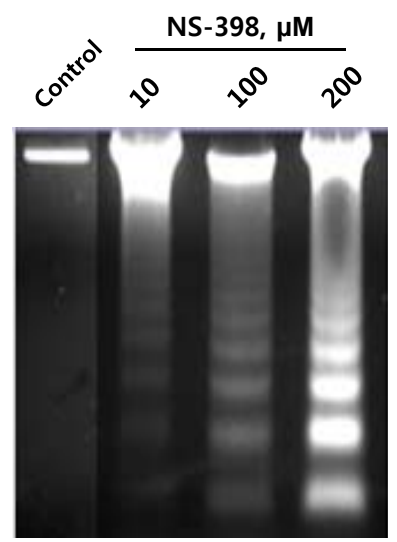

Figure 2. DNA fragmentation gel analysis. Ladderpatterned DNA fragmentations of Hep3B cells were noted at $48 \mathrm{~h}$ after treatment of NS-398 in concentrations of $10,100,200 \mu \mathrm{M}$, while no definite DNA ladder was found in DMSO control. 


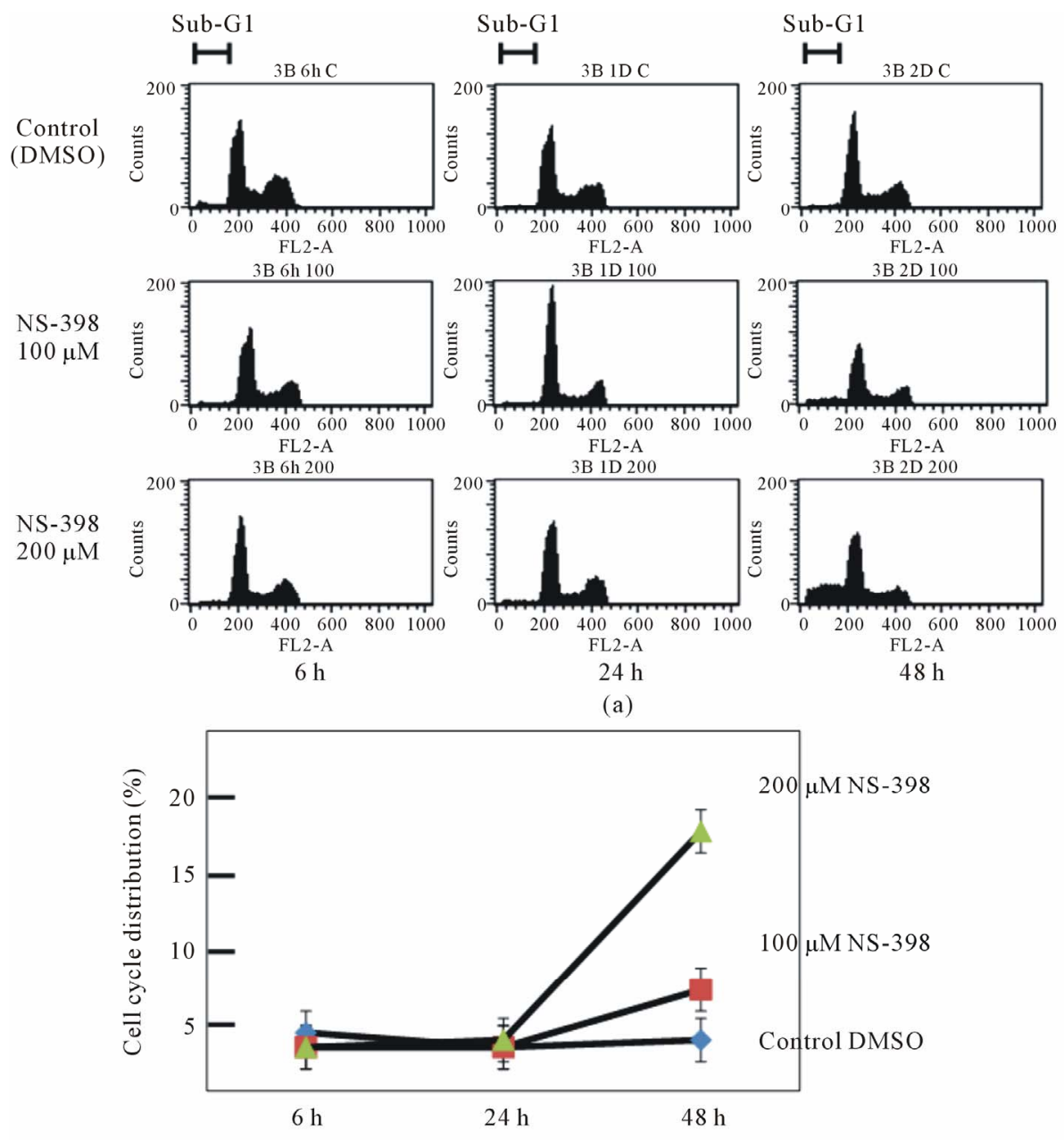

(b)

Figure 3. Cell cycle distribution by flow cytometry. Flow cytometric redistribution of cell cycle was gradually headed toward sub-G1 phase in time sequences from $6 \mathrm{~h}$ to $24 \mathrm{~h}$ and 48 $\mathrm{h}$ after exposure of NS-398, while it was not observed during same periods in control part of DMSO treatment (a) and (b). This cytometric redistribution to sub-G1 phase was more notable in $200 \mu \mathrm{M}$ NS-398-treated cells than in cells treated with $100 \mu \mathrm{M}$ concentration.

signaling pathway in HCC cells.

\section{DISCUSSION}

The greater parts of HCC are usually beyond the therapeutic indications of locoregionally curative measures, allowing many clinical researchers to keep attempting to excavate the therapeutic targets with its corresponding therapeutic agents in clinical studies. Although HCC has appeared to be chemoresistant in the response rate and to show no or minimal survival benefit in meta-analysis for the results of randomized controlled trials of systemic chemotherapy [24], extensive efforts for further improvement of clinical outcome in this liver cancer are ongoing under intensive investigations.

In malignant tumors, COX-2 is one of the therapeutic targets, which has been comprehensively studied around the world. Up to date, there have been several preclinical studies in vitro that up-regulation of COX-2 was known to reduce the rate of apoptosis, to promote angiogenesis and to increase the invasiveness of tumor cells [25-28]. Furthermore, selective COX-2 inhibition was reported to elicit an antineoplastic effect on HCC cells, to prevent the resistance to apoptosis as well as to suppress the growth of human HCC implants in vivo study using a nude mice $[12,13,18,29]$. A series of epidemiologic studies have revealed that non-steroidal anti-inflammatory drugs and aspirin could reduce the relative risk of death by colon cancer [30,31]. A couple of COX-2 selective drugs is also known to have the therapeutic potential to decrease the number and size of colonic polyps in patients with familial adenomatous polyposis [32-34], resulting in the advent of celecoxib approved by US Food and Drug Administration for chemoadjuvant therapy in 


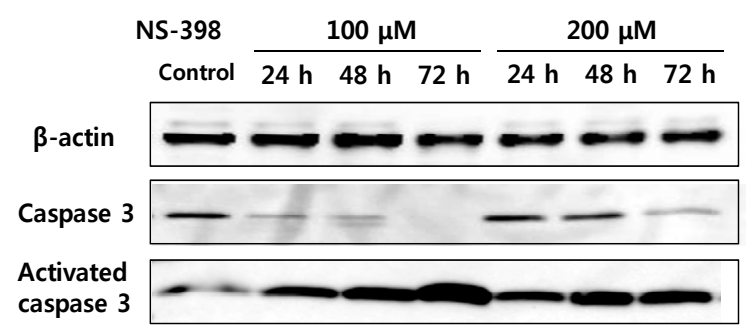

(a)

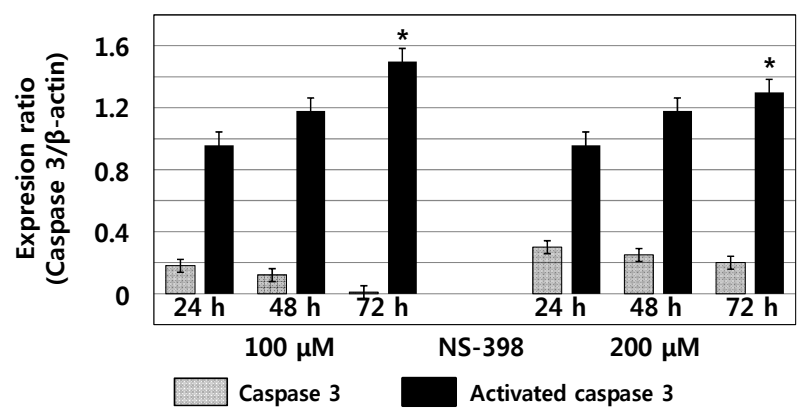

(b)

Figure 4. Caspase activity after treatment of NS-398. (a) The activity of caspase 3, a down-stream caspase of apoptosis, was evaluated by Western blot analysis; (b) The expression of cleaved form $(19 \mathrm{kDa})$ of caspase 3 gradually increased on time sequence from $24 \mathrm{~h}$ to $72 \mathrm{~h}$ after both concentrations 100 and $200 \mu \mathrm{M}$ of NS-398 treatment to Hep3B cells in time-dependent manner. It may be indicated that NS-398 involves a caspasedependent apoptosis signaling pathway in HCC cells. ${ }^{*} \mathrm{P}<0.05$, compared with the relative expression of activated caspase 3 at $24 \mathrm{~h}$ after treatment of NS-398.

these patients. However, the exact mechanisms responsible for explaining these growth-inhibitory effects of selective COX-2 inhibitor are not clear even to this time.

Based on our knowledges, together with experimental and clinical evidences mentioned above, that $\mathrm{COX}-2$ might play a pivotal role in tumorigenesis and overexpression of COX-2 has been observed in a number of tumor tissues, including colorectal cancer [9], pancreatic cancer [35], gastric cancer [27], esophageal cancer [36] and hepatocellular carcinoma [37], we conducted the present study that was designed for the clarification of inhibitory mechanisms and chemotherapeutic impact of NS-398, a selective COX-2 inhibitor, on the growth of hepatoma cells.

Our results showed that NS-398 definitely suppressed the growth of Hep3B HCC cells in both concentrationdependent and time-dependent manner with a resultant consequence of decreased tumor cell number. Besides the decrease of cell number, cell morphology was changed to be microscopically elongated with its significance being not defined. This growth-inhibitory effect of NS-398 to hepatoma cells was verified as a result of the induction of apoptosis by indicating a distinct ladder patternedfragmentation of genomic DNA and significant redistri-

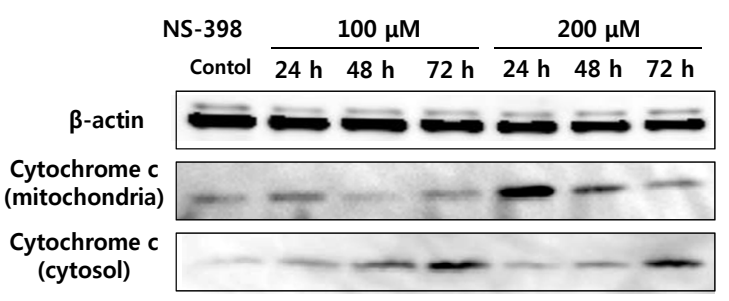

(a)

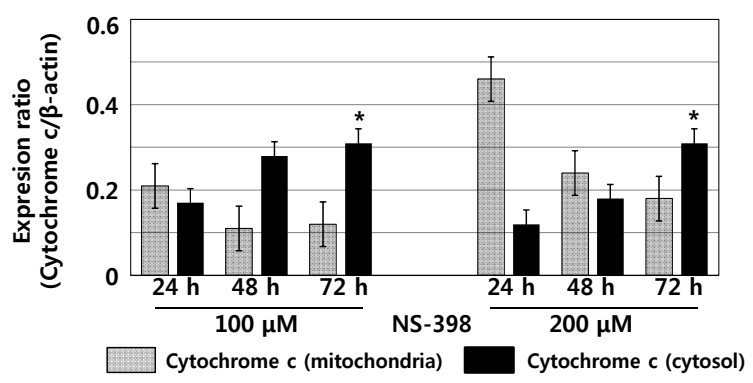

(b)

Figure 5. Localization of cytochrome c after treatment of NS398. (a) The activity of cytochrome c was evaluated by Western blot analysis; (b) The activity of cytosolic fraction of cytochrome c $(14 \mathrm{kDa})$ gradually increased on time sequence from $24 \mathrm{~h}$ to $72 \mathrm{~h}$, in opposition to that of mitochondrial fraction, following the treatment of both concentrations 100 and $200 \mu \mathrm{M}$ of NS-398, which means the cytoplasmic release of cytochrome c from mitochondria. It may be indicated that NS-398 engages a mitochondria-mediated intrinsic apoptosis signaling pathway in HCC cells. ${ }^{*} \mathrm{P}<0.05$, compared with the relative expression of cytosolic fraction of cytochrome c at $24 \mathrm{~h}$ after treatment of NS-398.

bution of cell cycle shifted to sub-G1 phase following NS-398 treatment. The strength of apoptosis-mediated growth inhibition of hepatoma cells was proportionally intensified according to the concentration of COX-2 inhibitor, which is allowed to be able to predict the dosedependent growth suppression of tumor cell.

Not only NS-398 but other COX-2 inhibitors such as nimesulide [13], CAY 10404 [13,17,38], celecoxib [16, 18], 2,5-dimethyl-celecoxib [39], meloxicam [12], JTE522 [40], sulindac [12] and indomethacin [13], have been introduced to the preclinical and clinical investigations designed for the identification of its growth-inhibitory mechanisms in tumorous conditions. Until now, the regulatory mechanisms of COX-2 inhibitors on the growth of tumor cells have appeared to depend on the various conditions, namely, a kind of COX-2 inhibitor compounds, a selectivity of COX-2 inhibition, a type of tumor cells, whether or not COX-2 expression in tumor cells, and an inhibitory dominancy of COX-2 inhibitor to COX-2 activity. Especially, The pattern of NS-398-induced growth suppression is thought to be variable according to the type of tumor cells: COX-2 expressing tumor cell lines such as GKCI-4 as well as Hep3B and COX-2 nonexpressing cell line such as HepG2 and PLC/PRE/5 [41]. 
The antitumor effects of NS-398 COX-2 inhibitor in HCC cells have been reported to be performed through the inhibitory signals via apoptosis, necrosis, or cell cycle arrest [19,40-43], however, most COX-2 inhibitors are generally accepted to be involved in the activation of apoptosis pathways which are advanced through the death receptor-mediated, mitochondria-mediated, or both signaling. There are several death receptors such as CD 95 (Fas receptor), tumor necrosis factor (TNF)-R, TNFrelated apoptosis-inducing ligand (TRAIL)-R1, and TRAIL-R2, that are known to be triggered by COX-2 inhibition [17,18].

Besides apoptotic activity via death receptors, several different mechanisms of COX-2 inhibitor relevant to apoptosis signal were investigated as follows: 1) downregulation of myeloid cell leukemia-1 (Mcl-1); 2) decreased expression of Bcl-2 antiapoptotic family; 3) down-regulation of surviving; 4) inhibition of mitogenantivated protein (MAP)/extracellular signal-regulated kinase (ERK) kinase (MEK)/ERK (MEK/ERK) signaling pathway; 5) reduction of serine/threonine protein kinase B (Akt) phosphorylation; 6) up-regulation of peroxisome proliferator-activated receptor (PPAR)- $\gamma$ protein; 7) increased expression of Fas ligand $[18,26,38,40-42,44]$.

Caspase 3, one of down-stream proteases for the execution of apoptotic programmed death in any type of insulted cells, is a final common pathway for the propagation of both extrinsic/death receptor-mediated or intrinsic/mitochondria-mediated apoptosis signals [19]. Our study revealed that the enzymatic activation of caspase 3 increased up to $72 \mathrm{~h}$ following treatment of Hep3B cells with NS-398. This finding was accompanied by a gradual accumulation of cytoplasmic fraction of cytochrome $\mathrm{c}$ up to $72 \mathrm{~h}$ after NS-398 treatment in both concentrations of 100 and $200 \mu \mathrm{M}$, suggesting a gradual release of cytochrome c from mitochondria. Both activetion of cleaved form of down-stream caspase and cytoplasmic translocation of cytochrome $\mathrm{c}$ are a hallmark of intrinsic aspoptosis signaling pathway.

\section{CONCLUSION}

NS-398, a selective COX-2 inhibitor, induced the growth inhibition of hepatoma cells through the caspase-dependent, mitochondria-mediated intrinsic apoptosis, providing a strong insight into the anti-neoplastic effects of selective COX-2 inhibitors as novel one of therapeutic agents for hepatocellular carcinoma. In the near future selective COX-2 inhibitors would be expected to try for the application to managements of HCC in clinical fields.

\section{ACKNOWLEDGEMENTS}

The financial support provided by the Institute of Medical Science Research of Dankook University Medical Center in 2008 for the pre- sent work is thankfully acknowledged.

\section{REFERENCES}

[1] El-Serag, H.B. and Rudolph, K.L. (2007) Hepatocellular carcinoma: Epidemiology and molecular carcinogenesis. Gastroenterology, 132, 2557-2576. doi:10.1053/i.gastro.2007.04.061

[2] Sherman, M. (2005) Hepatocellular carcinoma: Epidemiology, risk factors, and screening. Seminar in Liver Disease, 25, 143-154. doi:10.1055/s-2005-871194

[3] Song, I.H. and Kim, K.S. (2009) Current status of liver diseases in Korea: Hepatocellular carcinoma. Korean Journal of Hepatology, 15, S50-S59. doi:10.3350/kjhep.2009.15.S6.S50

[4] Lopez, P.M., Villanueva, A. and Llovet, J.M. (2006) Systematic review: Evidence-based management of heaptocellular carcinoma-An updated analysis of randomized controlled trials. Alimentary Pharmacology and Therapeutics, 23, 1535-1547. doi:10.1111/j.1365-2036.2006.02932.x

[5] Llovet, J.M., Ricci, S., Mazzaferro, V., Hilgard, P., Gane, E., Blanc, J.F., de Oliveira, A.C., Santoro, A., Raoul, J.L., Forner, A., Schwartz, M., Porta, C., Zeuzem, S., Bolondi, L., Greten, T.F., Galle, P.R., Seitz, J.F., Borbath, I., Häussinger, D., Giannaris, T., Shan, M., Moscovici, M. Voliotis, D. and Bruix, J.; SHARP Investigators Study Group. (2008) Sorafenib in advanced hepatocellular carcinoma. New England Journal Medicine, 359, 378-390. doi:10.1056/NEJMoa0708857

[6] Cheng, A.L., Kang, Y.K., Chen, Z., Tsao, C.J., Qin, S., Kim, J.S., Luo, R., Feng, J., Ye, S., Yang, T.S., Xu, J., Sun, Y., Liang, H., Liu, J., Wang, J., Tak, W.Y., Pan, H., Burock, K., Zou, J., Voliotis, D. and Guan, Z. (2009) Efficacy and safety of sorafenib in patients in the Asia-Pacific region with advanced hepatocellular carcinoma: A phase III randomised, double-blind, placebo-controlled trial. Lancet Oncology, 10, 25-34. doi:10.1016/S1470-2045(08)70285-7

[7] Koga, H. (2003) Hepatocellular carcinoma: Is there a potential for chemoprevention using cyclooxygenase-2 inhibitors? Cancer, 98, 661-667. doi:10.1002/cncr.11576

[8] Chang, W.S., Yang, M.D., Tsai, C.W., Cheng, L.H., Jeng, L.B., Lo, W.C., Lin, C.H., Huang C.Y. and Bau, D.T. (2012) Association of cyclooxygenase 2 single-nucleotide polymorphisms and hepatocellular carcinoma in Taiwan. Chinese Journal of Physiology, 55, 1-7.

[9] Ogunwobi, O.O., Wang, T., Zhang, L. and Liu, C. (2012) Cyclooxygenase-2 and Akt mediate multiple growthfactor-induced epithelial-mesenchymal transition in human hepatocellular carcinoma. Journal of Gastroenterology and Hepatology, 27, 566-578. doi:10.1111/j.1440-1746.2011.06980.x

[10] Nzeako, U.C., Guicciardi, M.E., Yoon, J.H., Bronk, S.F. and Gores, G.J. (2002) COX-2 inhibits Fas-mediated apoptosis in cholangiocarcinoma cells. Hepatology, 35, 552-559. doi:10.1053/jhep.2002.31774

[11] Abiru, S., Nakao, K., Ichikawa, T., Migita, K., Shigeno, 
M., Sakamoto, M., Ishikawa, H., Hamasaki, K., Nakata, K. and Eguchi, K. (2002) Aspirin and NS-398 inhibit hepatocyte growth factor-induced invasiveness of human hepatoma cells. Hepatology, 35, 1117-1124. doi:10.1053/jhep.2002.32676

[12] Kern, M.A., Schoneweiss, M.M., Sahi, D., Bahlo, M., Haugg, A.M., Kasper, H.U., Dienes, H.P., Käferstein, H., Breuhahn, K. and Schirmacher, P. (2004) Cyclooxygenase-2 inhibitors suppress the growth of human heaptocellular carcinoma implants in nude mice. Carcinogenesis, 25, 1193-1199. doi:10.1093/carcin/bgh110

[13] Fodera, D., D’Alessandro, N., Cusimano, A., Poma, P., Notarbartolo, M., Lampiasi, N., Montalto, G. and Cervello, M. (2004) Induction of apoptosis and inhibition of cell growth in human hepatocellular carcinoma cells by COX-2 inhibitors. Annals of the New York Academy of Sciences, 1028, 440-449. doi:10.1196/annals.1322.052

[14] Li, S., Tong, Q., Zhang, W., Wang, Q., Chen, Z. and Wu, Q. (2008) Mechanism of growth inhibitory effects of cyclooxygenase-2 inhibitor-NS398 on cancer cells. Cancer Investigation, 26, 333-337. doi:10.1080/07357900701788056

[15] Nakamoto, N., Higuchi, H., Kanamori, H., Kurita, S., Tada, S., Takaishi, H., Toda, K., Yamada, T., Kumagai, N., Saito, H. and Hibi, T. (2006) Cyclooxygenase-2 inhibitor and interferon-beta synergistically induce apoptosis in human hepatoma cells in vitro and in vivo. International Journal of Oncology, 29, 625-635.

[16] Xie, H., Gao, L., Chai, N., Song, J., Wang, J., Song, Z., Chen, C., Pan, Y., Zhao, L., Sun, S., Wu, K., Feitelson, M.A., Liu, J. and Fan, D. (2009) Potent cell growth inhibitory effects in hepatitis $\mathrm{B}$ virus $\mathrm{X}$ protein positive hepatocellular carcinoma cells by the selective cyclooxygenase-2 inhibitor celecoxib. Molecular Carcinogenesis, 48, 56-65. doi:10.1002/mc.20455

[17] Yamanaka, Y., Shiraki, K., Inoue, T., Miyashita, K., Fuke, H., Yamaguchi, Y., Yamamoto, N., Ito, K., Sugimoto, K. and Nakano, T. (2006) COX-2 inhibitors sensitize human hepatocellular carcinoma cells to TRAIL-induced apoptosis. International Journal of Molecular Medicine, 18, 41-47.

[18] Kern, M.A., Haugg, A.M., Koch, A.F., Schilling, T., Breuhahn, K., Walczak, H., Fleischer, B., Trautwein, C., Michalski, C., Schulze-Bergkamen, H., Friess, H., Stremmel, W., Krammer, P.H., Schirmacher, P. and Müller, M. (2006) Cyclooxygenase-2 inhibition induces apoptosis signaling via death receptors and mitochondria in heaptocellular carcinoma. Cancer Research, 66, 7059-7066. doi:10.1158/0008-5472.CAN-06-0325

[19] Okada, H. and Mak, T.W. (2004) Pathways of apoptotic and non-apoptotic death in tumour cells. Nature Reviews Cancer, 4, 592-603. doi:10.1038/nrc1412

[20] Budihardjo, I., Oliver, H., Lutter, M., Luo, X. and Wang, X. (1999) Biochemical pathways of caspase activation during apoptosis. Annual Review of Cell and Developmental Biology, 15, 269-290.

doi:10.1146/annurev.cellbio.15.1.269

[21] Salvesen, G.S. and Dixit, V.M. (1997) Caspases: Intracellular signaling by proteolysis. Cell, 91, 443-446.
doi:10.1016/S0092-8674(00)80430-4

[22] Thornberry, N.A. and Lazebnik, Y. (1998) Caspases: Enemies within. Science, 281, 1312-1316. doi:10.1126/science.281.5381.1312

[23] Goldstein, J.C., Waterhouse, N.J., Juin, P., Evan, G.I. and Green, D.R. (2000) The coordinate release of cytochrome c during apoptosis is rapid, complete and kinetically invariant. Nature Cell Biology, 2, 156-162. doi: $10.1038 / 35004029$

[24] Simonetti, R.G., Liberati, A., Angiolini, C. and Pagliaro, L. (1997) Treatment of hepatocellular carcinoma: A systematic review of randomized controlled trials. Annals of Oncology, 8, 117-136. doi:10.1023/A:1008285123736

[25] Lee, N.O., Park, J.W., Lee, J.A., Shim, J.H., Kong, S.Y., Kim, K.T. and Lee, Y.S. (2012) Dual action of a selective cyclooxygenase-2 inhibitor on vascular endothelial growth factor expression in human hepatocellular carcinoma cells: Novel involvement of discoidin domain receptor 2 . Journal of Cancer Research and Clinical Oncology, 138, 73-84. doi:10.1023/A:1008285123736

[26] Leng, J., Han, C., Demetris, A.J., Michalopoulos, G.K. and $\mathrm{Wu}, \mathrm{T}$. (2003) Cyclooxygenase-2 promotes hepatocellular carcinoma cell growth through Akt activation: Evidence for Akt inhibition in celecoxib-induced apoptosis. Hepatology, 38, 756-768. doi:10.1053/jhep.2003.50380

[27] Li, H.X., Chang, X.M., Song, Z.J. and He, S.X. (2003) Correlation between expression of cyclooxygenase-2 and angiogenesis in human gastric adenocarcinoma. World Journal of Gastroenterology, 9, 674-677.

[28] Ogunwobi, O.O. and Liu, C. (2011) Hepatocyte growth factor upregulation promotes carcinogenesis and epithetlial-mesenchymal transition in hepatocellular carcinoma via Akt and COX-2 pathway. Clinical and Experimental Metastasis, 28, 721-731. doi:10.1007/s10585-011-9404-X

[29] Kern, M.A., Schubert, D., Sahi, D., Schöneweiss, M.M., Moll, I., Haugg, A.M., Dienes, H.P., Breuhahn, K. and Schirmacher, P. (2002) Proapoptotic and antiproliferative potential of selective cyclooxygenase- 2 inhibitors in human liver tumor cells. Hepatology, 36, 885-894.

[30] Thun, M.J., Namboodiri, M.M. and Heath Jr., C.W. (1991) Aspirin use and reduced risk of fatal colon cancer. New England Journal of Medicine, 325, 1593-1596. doi:10.1056/NEJM199112053252301

[31] Giovannucci, E., Egan, K.M., Hunter, D.J., Stampfer, M.J., Colditz, G.A., Willett, W.C. and Speizer, F.E. (1995) Aspirin and the risk of colorectal cancer in women. New England Journal of Medicine, 333, 609-614. doi:10.1056/NEJM199509073331001

[32] Labayle, D., Fischer, D., Vielh, P., Drouhin, F., Pariente, A., Bories, C., Duhamel, O., Trousset, M. and Attali, P. (1991) Sulindac causes regression of rectal polyps in familial adenomatous polyposis. Gastroenterology, 101, 635-639.

[33] Van Stolk, R., Stoner, G., Hayton, W.L., Chan, K., DeYoung, B., Kresty, L., Kemmenoe, B.H., Elson, P., Rybicki, L., Church, J., Provencher, K., McLain, D., Hawk, E., Fryer, B., Kelloff, G., Ganapathi, R. and Budd, G.T. (2000) Phase I trial of exisulind (sulindac sulfone, FGN-1) 
as a chemopreventive agent in patients with familial adenomatous polyposis. Clinical Cancer Research, 6, 78-89.

[34] Steinbach, G., Lynch, P.M., Phillips, R.K., Wallace, M.H., Hawk, E., Gordon, G.B., Wakabayashi, N., Saunders, B., Shen, Y., Fujimura, T., Su, L.K. and Levin, B. (2000) The effect of celecoxib, a cyclooxygenase- 2 inhibitor, in familial adenomatous polyposis. New England Journal of Medicine, 342, 1946-1952. doi:10.1056/NEJM200006293422603

[35] Tucker, O.N., Dannenberg, A.J., Yang, E.K., Zhang, F., Teng, L., Daly, J.M., Soslow, R.A., Masferrer, J.L., Woerner, B.M., Koki, A.T. and Fahey III, T.J. (1999) Cyclooxygenase-2 expression is up-regulated in human pancreatic cancer. Cancer Research, 59, 987-990.

[36] Zimmermann, K.C., Sarbia, M., Weber, A.A., Borchard, F., Gabbert, H.E. and Schror, K. (1999) Cyclooxygenase2 expression in human esophageal carcinoma. Cancer Research, 59, 198-204.

[37] Qiu, D.K., Ma, X., Peng, Y.S. and Chen, X.Y. (2002) Significance of cyclooxygenase-2 expression in human primary hepatocellular carcinoma. World Journal of Gastroenterology, 8, 815-817.

[38] Cusimano, A., Fodera, D., D’Alessandro, N., Lampiasi, N., Azzolina, A., Montalto, G. and Cervello, M. (2007) Potentiation of the antitumor effects of both selective cyclooxygenase- 1 and cyclooxygenase- 2 inhibitors in human hepatic cancer cells by inhibition of the MEK/ ERK pathway. Cancer Biology and Therapy, 6, 14611468. doi:10.4161/cbt.6.9.4629

[39] Pyrko, P., Soriano, N., Kardosh, A., Liu, Y.T., Uddin, J., Petasis, N.A., Hofman, F.M., Chen, C.S., Chen, T.C. and
Schönthal, A.H. (2006) Downregulation of survivin expression and concomitant induction of apoptosis by celecoxib and its non-cyclooxygenase-2-inhibitory analog, dimethyl-celecoxib (DMC), in tumor cells in vitro and in vivo. Molecular Cancer, 5, 19. doi:10.1186/1476-4598-5-19

[40] Nagahara, T., Okano, J. and Murawaki, Y. (2007) Mechanisms of anti-proliferative effect of JTE-522, a selective cyclooxygenase- 2 inhibitor, on human liver cancer cells. Oncology Reports, 18, 1281-1290.

[41] Cheng, A.S., Chan, H.L., Leung, W.K., Wong, N., Johonson, P.J. and Sung, J.J. (2003) Specific COX-2 inhibitor. NS-398, suppresses cellular proliferation and induces apoptosis in human hepatocellular carcinoma cells. International Journal of Oncology, 23, 113-119.

[42] Yu, Y., Gong, R., Mu, Y., Chen, Y., Zhu, C., Sun, Z., Chen, M., Liu, Y., Zhu, Y. and Wu, J. (2011) Hepatitis B virus induces a novel inflammation network involving three inflammatory factors, IL-29, IL-8, and cyclooxygenase-2. Journal of Immunology, 187, 4844-4860. doi:10.4049/jimmunol.1100998

[43] Baek, J.Y., Hur, W., Wang, J.S., Bae, S.H. and Yoon, S.K. (2007) Selective COX-2 inhibitor, NS-398, suppresses cellular proliferation in human hepatocellular carcinoma cell lines via cell cycle arrest. World Journal of Gastroenterology, 13, 1175-1181.

[44] Huang, D.S., Shen, K.Z., Wei, J.F., Liang, T.B., Zheng, S.S. and Xie, H.Y. (2005) Specific COX-2 inhibitor NS398 induces apoptosis in human liver cancer cell line HepG2 through BCL-2. World Journal of Gastroenterology, 11, 204-207. 